\title{
THE ROLE OF ACCOUNTANT IN THE ESTONIAN ENTERPRISE
}

\section{Ottoson, E., Nikitina-Kalamae, M., Gurvitš, N.'}

Recent developments and changes in the modern economy as well as falls and rises of large corporations have brought up the public interest towards the accounting discipline, and have resulted in a growing demand for accountant specialists as educated professionals. The aim of the present research is to find out what is the role of the accountant in the modern enterprise. The authors conducted a survey among Estonian accounting specialists and managers. The results of the survey clearly indicate that in most Estonian companies, accountants are actively assisting members of the board to make vital decisions, and their competence, knowledge and skills are highly valued by managers. The findings of the survey emphasize that Estonian accountants are highly qualified, keeping in line with the latest developments in the modern financial world.

Keywords: accountant; accountant competencies; accountant tasks; accountant responsibilities; accountant's role

\section{JEL classification: M41}

\section{Introduction}

Recent developments and changes in the modern economy as well as the falls and rises of large corporations have brought up the public interest towards the accounting discipline and have resulted in a growing demand for accountant specialists as educated professionals. For ages, accountants seemed to be associated with calculations and "debit-credit" rules. It is not a secret that even today people consider the accounting profession to be unexciting, lacking in drive and creativity, and limited to the preparation of annual reports by a stipulated date.

However, in regard to the latest financial scandals, the first ones to blame appear to be accountants and auditors, whom the stakeholders consider as "watchdogs and noble knights" serving public interests and preventing the managers and shareholders from going too deep into the money-making world of greediness. Today "accounting is a profession which has as its function the providing of the conditions of trust in a modern market economy" (Cheffers and Pakaluk, 2007). It seems that accountants today are regarded as the conductors of "true and fair" representation, transparency and verified financial information. Prentice, (2001) in his works, named accounting not as a trade but a "learned profession". The common public opinion considers accountants not as businessmen but as educated professionals, which is not always the case, as stated by David Logan's Northern Ireland company McIlveen Howard during a panel session with other accountants: "Accountancy is now becoming a trade not a profession" (Accounting...).

So, what are the main attributes of the modern accounting profession and has there been a shift from a "learned professional" towards "smart accountant-businessman"?

An earlier version of this paper was presented at WEI International Academic Conference on May 30-31, 2016 in Prague; however, it contained the opinions of accountants only. 
Taylor and Osipenkova (2003) stated that during the era of Soviet Union, accountants were trained as bookkeepers and not as skilled professionals playing a vital role in the company business activity. Stuart et al. (2014) outline two vital dimensions of the accountant's competence - technical proficiency and ethical sensibility and therefore define four types of accountants:

- The Destructive Accountant - lacking both technical and ethical competence.

- The Good-hearted Accountant - characterized by ethical sensibility but lacking technical competence.

- The Opportunistic Accountant - characterized by technical competence but lacking ethical competence.

- The Virtuous Accountant - characterized by both technical and ethical competences. (Stuart et al., 2014)

It is obvious that there seems to be a wide range of accountants with different competences, knowledge and skills, and consequently they have different approaches to their everyday work responsibilities. Debates over the accounting competences, duties and responsibilities are not over; to date not many studies have been done in Estonia in order to define the role of the accountant in the modern company; this gap the authors are filling in by the present study.

\section{Review of Literature and Research Question}

Numerous research studies have been done in various countries to determine the main responsibilities of accountants; among the most outstanding, we can cite the studies of Albu et al (2011), Antipova (2013), Malone and Van der Stede (2010). Several studies have been carried out in regard to the accounting competence, and the necessary aspects of the accounting knowledge and skills. Flanagan and Clarke (2007) suggest that most accountants often fail to realize that their everyday work also includes an ethical dimension, the study of Parker (1987) identifies the main ethical issues of the Australian accounting profession.

The studies of Olivier (2000) identified two external drivers having a major impact on the accounting profession - regulatory framework and the developing information technologies, pointing out that the qualified staff will become an issue in the near future, taking into consideration the development of non-financial reporting. The latest developments in the field of financial and non-financial reporting totally confirm the findings of Davies (1979), stating that the liabilities of accountants to the stakeholders would become a matter of international concern.

Several studies outline the importance of the other factors such as age, gender and retaliation in determination of the paths of accountants' behavior and decisions making-process. Tsakumis (2007) identified the influence of culture on accountants' behavior while following the accounting rules; the studies revealed U.S. accountants to be more conservative than the Greek ones. Liyanarachchi and Adler (2011) investigated the impact of retaliation, age and gender on the intention to whistle-blow among the Certified Practicing Accountants of Australia and revealed a direct interaction effect.

Several studies investigated the personality of accountants, outlining the importance of such research. Aranya and Wheeler (1986) explored the linkage between different 
types of accountant personality and their commitment to work; Krambia-Kapardis and Zopiatis (2011) suggested that the personal values of the accountant are of a high importance to predict the possible reaction to the financial scandals; their findings revealed that in general, accountants "value 'head' more than 'heart"' (Krambia-Kapardis and Zopiatis, 2011). These findings suggest that in most situations, accountants would probably be guided by the "think first" principle.

It is also important to note that today, specialists working in the field of accounting and auditing are actively involved in the decision-making process, which is also confirmed by the studies of Mala and Chand (2015), who outline that judgement and decision making are an important attribute in the accounting profession. The studies of Albu et al., (2011) explored the impact of accounting reforms on the accounting specialist in Romania; the findings revealed a rapid move towards "hybridization process between financial accounting and management accounting positions" Albu et al., (2011). Harrison et al. (2005) examined the changes in the role of accountants over 30 years in an Australian government trading company, outlining the role accountants play in the "implementation of the stakeholders' agenda".

In line with the previous research, the authors of the present article are willing to fill the gap and find out the role of the accountant in a modern enterprise, how the Estonian accountants find themselves in the modern business world, and what is their opinion on their duties and responsibilities. The survey conducted in the present research to some extent replicates some of the abovementioned studies but also analyses the opinion of Estonian accountants and professionals on the role of the accountant in a modern company.

\section{Methodology}

The authors conducted a survey among two different groups of respondents: Estonian accounting specialists and company managers in 2015 via Google Forms environment. The questionnaire consisted of 11 questions, both multiple-choice and open-ended questions. After the questionnaire was prepared, a pilot survey was conducted among 35 respondents, to check that the system works properly, later these replies were deleted and the questionnaire was officially opened for the public. The survey took place in the period of 12.02-31.03.2015. The authors posted information about the survey calling to participate on the forums of the largest Estonian accounting portal (www.rmp.ee) and financial portal (www.finance.ee). The questionnaire was also sent to all master's degree students at the School of Economics and Business Administration of Tallinn University of Technology. The authors also personally asked accountants and managers to participate in the survey. In total, emails to 566 persons (298 accountants and 268 managers) were sent out; 179 responses were collected: 115 from accountants and 64 from company managers. The results of the survey were retrieved from Google form into Microsoft Excel; this information was then compiled and analyzed. Table 1 shows the profile of surveyed accountants. 
Table 1 | Demographic data of the survey among accountants

\begin{tabular}{|l|c|}
\hline Status & Sample \\
\hline Position & 62 \\
\hline Chief Accountant & 44 \\
\hline Accountant & 9 \\
\hline Assistant Accountant & 115 \\
\hline Total & \multicolumn{2}{|l|}{} \\
\hline Work experience & 21 \\
\hline 0-5 years & 24 \\
\hline 6-10 years & 14 \\
\hline $11-15$ years & 21 \\
\hline $16-20$ years & 35 \\
\hline 20 years and more & 115 \\
\hline Total & 115 \\
\hline Education & 32 \\
\hline High school & 39 \\
\hline Professional higher education & 91 \\
\hline Bachelor & 24 \\
\hline Master & \\
\hline Total & \\
\hline Type of education & \\
\hline Accounting & \\
\hline Other & \\
\hline Total & \multicolumn{2}{|l|}{} \\
\hline
\end{tabular}

Source: authorial computation based on the survey results

It should also be noted that 56 respondents stated that no other financial field related specialist is employed by the company they are currently working in.

\section{Results}

The authors would like to present the extract from the survey conducted among accountants represented by tables 2 till 5. In the authors' opinion, the selected questions are most challenging and worth discussion. In table 2 , there are listed statements of different tasks the respondents fulfil during their everyday work. 
Table 2 | Tasks and responsibilities the respondents from the accountant side fulfil during their everyday work (the respondents were allowed to choose several options)

\begin{tabular}{|l|c|c|}
\hline Type of task & $\begin{array}{c}\text { Number of } \\
\text { responses }\end{array}$ & $\begin{array}{c}\text { Responses } \\
\text { in \% }\end{array}$ \\
\hline Financial accounting & 109 & 94.78 \\
\hline External reporting & 104 & 90.43 \\
\hline Taxation accounting & 101 & 87.83 \\
\hline Payroll accounting & 88 & 76.52 \\
\hline Accounting information systems & 87 & 75.65 \\
\hline Managerial accounting & 76 & 66.09 \\
\hline Activities related to the management decision-making process & 72 & 62.61 \\
\hline Other & 18 & 15.65 \\
\hline
\end{tabular}

Source: authorial computation based on the survey results

The data of table 2 clearly indicates that the most common tasks for the respondents seem the ones related to financial accounting, external reporting and taxation accounting. Managerial accounting related tasks and various activities related to the management decision-making process seem less common.

Table 3 represents the respondents' opinion regarding their competence and everyday working activities.

Table 3 | Respondents' opinions on the selected statements in number of responses

\begin{tabular}{|c|c|c|c|}
\hline Statement & Very often & Sometimes & No \\
\hline $\begin{array}{l}\text { In my everyday work, I prepare documents/reports/ } \\
\text { calculations for the management in order to assist them in the } \\
\text { decision-making process. }\end{array}$ & 54 & 55 & 6 \\
\hline $\begin{array}{l}\text { Members of the board ask for my opinion before making the } \\
\text { final decision. }\end{array}$ & 32 & 62 & 21 \\
\hline $\begin{array}{l}\text { My competence makes it possible for me to prepare } \\
\text { documents/reports/calculations for the management in order } \\
\text { to assist them in the decision-making process. }\end{array}$ & 63 & 47 & 5 \\
\hline $\begin{array}{l}\text { My competence makes it possible for me to give advice to the } \\
\text { members of the board to make decisions. }\end{array}$ & 52 & 52 & 11 \\
\hline
\end{tabular}

Source: authorial computation based on the survey results

Results of the survey shown in table 3 clearly indicate that rather a small amount of respondents - less than $20 \%$ are not participating in decision-making process and 
have never been asked for their opinion before the management makes its final decision. Also less than $10 \%$ of the respondents consider their competence inappropriate for giving advice to the members of the board, which may also be explained by the fact that these respondents are underestimating their knowledge and skills. Worth attention is the fact that 21 respondents $-18.26 \%$, stated that their competence does not enable them to prepare the documents required by management to make decisions. In the authors' opinion, it may be explained by the fact that these accountants are used to fulfilling routine tasks related to everyday business activities and not prepared to "think out of the box".

Table 4 illustrates the frequency of asking for the accountant's opinion before making the final decision depending on the company size.

Table 4 | Responses to the statement that members of the board ask for the accountant's opinion before making a final decision

\begin{tabular}{|l|c|c|c|}
\hline Type of company & Very often & Sometimes & No \\
\hline Companies with 1-9 employees & $44 \%$ & $39 \%$ & $17 \%$ \\
\hline Companies with 10-49 employees & $32 \%$ & $57 \%$ & $11 \%$ \\
\hline Companies with 50-249 employees & $24 \%$ & $54 \%$ & $22 \%$ \\
\hline Companies with 250 and more employees & $6 \%$ & $63 \%$ & $31 \%$ \\
\hline
\end{tabular}

Source: authorial computation based on the survey results

The results of the survey shown in table 4 clearly demonstrate that the size of the company really matters: the more employees that work in the company, the less often management consults with the accountant before making final decisions. In the authors' opinion, that may be explained by the fact that in large companies the management is represented by highly educated people with financial background who consider themselves competent enough to make decisions.

Table 5 illustrates how often the respondents prepare all sorts of documentation vital for the management to make the final decisions.

Table 5 | Respondent prepares documents/reports/calculations for the management in order to assist them in the decision-making process

\begin{tabular}{|l|c|c|c|}
\hline Type of company & Very often & Sometimes & No \\
\hline Companies with 1-9 employees & $44 \%$ & $50 \%$ & $6 \%$ \\
\hline Companies with 10-49 employees & $52 \%$ & $43 \%$ & $5 \%$ \\
\hline Companies with 50-249 employees & $49 \%$ & $46 \%$ & $5 \%$ \\
\hline Companies with 250 and more employees & $31 \%$ & $63 \%$ & $6 \%$ \\
\hline
\end{tabular}

Source: authorial computation based on the survey results 
The results of the survey shown in table 5 indicate that only a small percentage of respondents have never prepared any sort of documentation needed by management to make a final decision. Again, most often accountants prepare such documentation in companies with 10-49 employees, and least often in large companies with more than 50 employees. In the authors' opinion, large companies practice clear delegation of responsibilities among the employees; therefore, they may attract external financial specialists to prepare such documentation.

Tables 6-8 represent the extract from the responses of the managers. In the authors' opinion, the selected questions are most challenging and worth discussion. Table 6 summarizes the opinion of managers on the role of accountants in a modern enterprise.

Table 6 | Managers' opinions on the role of accountants in a modern enterprise

\begin{tabular}{|l|c|}
\hline Role of accountant & Responses (\%) \\
\hline $\begin{array}{l}\text { A person who deals with accounting making sure that this job is done } \\
\text { properly and correctly }\end{array}$ & 22 \\
\hline $\begin{array}{l}\text { A person who deals with accounting and gives advice to manager of the } \\
\text { company }\end{array}$ & 75 \\
\hline Other & 3 \\
\hline
\end{tabular}

Source: authorial computation based on the survey results

The data presented in table 6 shows that mostly accountants are regarded by managers as a valuable assistant, whose opinion matters in making various decisions.

Table 7 illustrates how often managers turn to accountants to get professional advice.

Table 7 | Responses of managers to the statement regarding competence of accountants

\begin{tabular}{|c|c|c|c|}
\hline Statement & Very often & Sometimes & No \\
\hline Managers ask accountant for the advice & $36 \%$ & $56 \%$ & $8 \%$ \\
\hline $\begin{array}{l}\text { Accountant's competence is sufficient to prepare } \\
\text { documents/reports/calculations }\end{array}$ & $44 \%$ & $42 \%$ & $14 \%$ \\
\hline $\begin{array}{l}\text { Accountant's competence is sufficient to give } \\
\text { managers advice }\end{array}$ & $48 \%$ & $42 \%$ & $10 \%$ \\
\hline
\end{tabular}

Source: authorial computation based on the survey results

The findings presented in table 7 illustrate that in most cases the accountant's competence is sufficient to fulfil various tasks and jobs and to give different advice to the managers. Only a small percentage of respondents (less than $10 \%$ ) indicated that they never ask accountants for advice.

Table 8 represents the managers' opinions regarding the competence and everyday working activities of the accountants. 
Table 8 | Tasks and responsibilities fulfilled by accountants during their workday, as seen by managers (the respondents were allowed to choose several options)

\begin{tabular}{|l|c|c|}
\hline Type of task & $\begin{array}{c}\text { Number of } \\
\text { responses }\end{array}$ & Responses in \% \\
\hline Financial accounting & 64 & 100 \\
\hline External reporting & 61 & 96 \\
\hline Taxation accounting & 64 & 96 \\
\hline Payroll accounting & 61 & 61 \\
\hline Accounting information systems & 35 & 55 \\
\hline Managerial accounting & 35 & 55 \\
\hline $\begin{array}{l}\text { Activities related to the management decision- } \\
\text { making process }\end{array}$ & 2 & 3 \\
\hline Other & & \\
\hline
\end{tabular}

Source: authorial computation based on the survey results

Table 8 clearly illustrates that financial accounting, taxation, payroll accounting and external reporting are the main responsibilities of accountants as seen by managers. However, it should be noted that more than half of the responding managers consider accountants as an assistant in the managerial decision-making process.

The results of the research clearly indicate that in Estonian enterprises, an accountant is not only the bookkeeper or calculating machine extended by the "debit-credit" function but a valued specialist fulfilling different tasks, whose opinion matters for the management. It should also be noted that the comparison of main tasks and responsibilities of an accountant as seen by accountants and managers has shown no significant differences (10\% or less). In many companies, accountants are actively assisting members of the board to make vital decisions, and their competence, knowledge and skills are highly valued by managers.

\section{Conclusion}

The study examined the role of accountants in the modern Estonian enterprise in regard to the responsibilities and tasks handled by them. In conclusion, it can be stated that Estonian accountants have a good combination of technical and ethical competence and provide stakeholders with the information they can trust. It can also be stated that in the majority of companies, the accountant is responsible for various tasks, and not concentrated on just the everyday routine job of a "bookkeeper". The findings of the survey have various implications. First, they emphasize that Estonian accountants are highly qualified, going in line with the latest developments in the modern financial world. Second, the education of accountants should be considered as highly important, promoted and inspired by the state, and provided by high educational institutions at the highest standards in order to fulfil the requirements of the rapidly changing and growing business world. 
The authors are aware that the study has several limitations. The role of accountants was determined by the opinion of two groups only, with an unequal amount of respondents,

leaving out major stakeholders like other users of financial statements such as auditors, bankers etc. The sample size of the survey is fairly small to make general conclusion valid for companies of all sizes about the current role of accountants in Estonia.

For the future research, the authors expect to broaden the scope and attract other users of financial statements, increase the sample by attracting more participants from the accountant and managerial sides, as well as include and provide multinational research and analysis among other Baltic States and Scandinavian countries.

\section{References}

Accounting Web (2012). Accountancy becoming trade not profession. Accounting Web [online]. Retrieved January 26, 2016, from http://www.accountingweb.co.uk/article/ accountancy-becoming-trade-not-profession/532393.

Albu, C. N., Albu, N., Faff, R., \& Hodgson, A. (2011). Accounting Competencies and the Changing Role of Accountants in Emerging Economies: The Case of Romania. Accounting in Europe, 8(2), 155-184.

Antipova, T. (2013). Changing roles of accountants. Global Conference on Business and Finance Proceedings, 8(1), 430-434.

Aranya, N., \& Wheeler, J. T. (1986). Accountants' personality types and their commitment to organization and profession. Contemporary Accounting Research, 3(1), 184-199. doi: 10.1111/j.1911-3846.1986.tb00633.x

Cheffers, M., \& Pakaluk, M. (2007). Understanding Accounting Ethics. Sutton, MA: Allen David Press.

Davies, J. J. (1979). Accountants' Third Party Liability: A History of Applied Sociological Jurisprudence. Abacus, 15(2), 93-112. doi: 10.1111/j.1467-6281.1979.tb00077.x

Flanagan, J., \& Clarke, K. (2007). Beyond a Code of Professional Ethics: A Holistic Model of Ethical Decision-Making for Accountants. Abacus, 43(4), 488-518. doi: 10.1111/j.1467-6281.2007.00242.x

Harrison, G., Mckinnon, J., \& Perera, S. (2005). The Role and Status of Accounting and Accountants in an Australian Government Trading Enterprise: A Stakeholder Approach. Pacific Accounting Review, 17(2), 112-151.

Krambia-Kapardis, M., \& Zopiatis, A. (2011). Personal values of accountants and accounting trainees in Cyprus. Business Ethics: A European Review, 20(1), 59-70. doi: 10.1111/j.1467-8608.2010.01606.x

Liyanarachchi, G. A., \& Adler, R. (2011). Accountants'Whistle-Blowing Intentions: The Impact of Retaliation, Age, and Gender. Australian Accounting Review, 21(2), 167-182. doi: 10.1111/j.1835-2561.2011.00134.x

Mala, R. and Chand, P. (2015). Judgment and Decision-Making Research in Auditing and Accounting: Future Research Implications of Person, Task, and Environment Perspective. Accounting Perspectives, 14, 1-50. doi: 10.1111/1911-3838.12040

Malone, R., \& Van der Stede, W. A. (2010). Accounting trends in a borderless world. - World Congress of Accountants, 8.-11. November 2010. Retrieved January 26, 2016, from http:// www.cimaglobal.com/Documents/Thought_leadership_docs/AccountingTrends.pdf. 
Olivier, H. (2000). Challenges facing the accountancy profession. European Accounting Review, 9(4), 603-624.

Parker, L. D. (1987). An Historical Analysis of Ethical Pronouncements and Debate in the Australian Accounting Profession. Abacus, 23(2), 122-138. doi: 10.1111/j.14676281.1987.tb00145.x

Prentice, R. A. (2001). The case of educating legally aware accountants. Retrieved January 26, 2016, from http://www.javeriana.edu.co/personales/hbermude/areacontable/ particulares/4943695.pdf.

Stuart, I., Stuart, B., \& Pedersen, L. J. T. (2014). Accounting Ethics. New York: John Wiley \& Sons.

Taylor, T. C. \& Osipenkova, O. (2003). Management accounting in Russia: a work in process. Cost Management, 17(3), 39-45.

Tsakumis, G. T. (2007). The influence of culture on accountants' application of financial reporting rules. Abacus, 43(1), 27-48. doi: 10.1111/j.1467-6281.2007.00216.x

\section{Authors}

\section{Ergo Ottoson}

Practitioner, Graduated MA Student

Tallinn University of Technology

Akadeemia tee 3, 12618 Tallinn, Estonia

ergo.ottoson@mail.ee

\section{Monika Nikitina-Kalamae}

Lecturer of Financial Accounting

Tallinn University of Technology

Akadeemia tee 3, 12618 Tallinn, Estonia

monika.nikitina-kalamae@ttu.ee

\section{Dr. Natalja Gurvitš}

Associate Professor of Financial Accounting

Tallinn University of Technology

Akadeemia tee 3, 12618 Tallinn, Estonia

natalja.gurvits@ttu.ee 